\title{
Toplumsal Cinsiyetin Bir Aktarım Aracı Olarak Çizgi Filmler: Sindirella ve Pamuk Prenses Örneği
}

\section{Cartoons As A Transmitting Tool Of Gender: Cinderella And Snow White Case}

Prof. Dr. Dolunay ŞENOL ${ }^{1}$, Sezgin ERDEM ${ }^{2}$, Zafer UZUN $^{3}$, Elif ERDEM ${ }^{4}$

$\ddot{O} z$

$\mathrm{M}$ asal, içinde bulunduğu toplumun normlarının, stereotiplerinin, baskın düşüncelerinin, örtük kodlarının ve kültürel unsurlarının yeniden üretiminde etken bir rol üstlenmektedir. 2-5 yaş arası çocuk grubuna hitap eden bu masallar, sundukları görsel materyaller ile çocukların sosyalizasyonlarına katkı sağlamaktadır. Günümüzde çocukların psiko-sosyal gelişimlerine katkıda bulunmak ve onları eğlendirmek amacıyla görselliğin daha etkin bir şekilde kullanıldığı masalları konu alan çizgi filmlerin sayıları gittikçe artmaktadır. Ebeveynler bu çizgi film masallarını çocuklarına satın alarak ve izleterek çocuklarının toplumsallaşma sürecine katkıda bulunmaktadırlar. Bu bağlamda toplumsal cinsiyete ilişkin inşa edilmiş kodların, masalları konu alan çizgi filmler üzerinden aktarımının incelenmesi eril tahakkümün örtük kodlarının keşfedilmesi açısından önem taşımaktadır. Bu araştırmanın konusunu toplumsal cinsiyet kodlarının bir aktarım aracı olarak kullanıldığı "Külkedisi: Sindirella” ve "Pamuk Prenses ve Yedi Cüceler" adlı çizgi filmlerde toplumsal cinsiyet kodlarının hangi biçimlerde işlendiği ve çözümlendiğinin incelenmesi oluşturmaktadır. Çalışmada "Külkedisi: Sindirella", "Pamuk Prenses ve Yedi Cüceler" masallarında yapılandırılan kadınlık temsillerinin irdelenerek, toplumsal cinsiyet organizasyonunun ne şekilde biçimlendirildiğinin içerik analizi yöntemiyle ortaya konulmaya çalışılmıştır. Toplumsal cinsiyete ilişkin kodların erken yaşlarda öğrenildiğini kabul edersek; çocukluk

1 Kırıkkale Üniversitesi Sosyoloji Bölüm Başkanı, senoldolunay@gmail.com

2 Doktora Öğrencisi, Kırıkkale Üniversitesi Sosyal Bilimler Enstitüsü, Sosyoloji Ana Bilim Dalı, sezginerdem84@gmail.com

3 Doktora Öğrencisi, Hacettepe Üniversitesi Sosyal Bilimler Enstitüsü, Sosyoloji Anabilim Dalı, zafer.uzzun@ gmail.com

4 Yüksek Lisans Öğrencisi, Gazi Üniversitesi Sosyal Bilimler Enstitüsü, Sosyoloji Ana Bilim Dalı, elif1986erdem@gmail.com 
döneminde bizlere de defalarca anlatılan ve aynı zamanda bu araştırmanın da konusu olan "Kül Kedisi: Sindirella" ve "Pamuk Prenses ve Yedi Cüceler" adlı masallarda çocuklara sunulan ve toplumdaki eril-dişil kimlik kodlarının en baştan nasıl şekillendirildiğini ortaya koyması açısından bu araştırma bulguları önem arz etmektedir.

Anahtar Kelimeler: Cinsiyet, Toplumsal cinsiyet, Masal, Çizgi film, İçerik analizi

\section{Abstract}

$\mathrm{T}$ ales have an active role in the reproduction of stereotypes, dominant thinking, norms of society, implicit codes and cultural elements. Tales that appeal to children between 2-5 years age group contribute also to their socialization with visual materials they offer. Today, the number of cartoons using tales which contribute to children's psycho-social development and entertain them is increasing. Parents contribute to the socialization process of children by buying them cartoon tales and showing these to their children. In this context, investigation of transmission of the codes built on gender through cartoons is important for the discovery of implicit codes of masculine domination. The goal of this research project is to constitute to the examination in which ways gender codes have been processed and resolved in the "Cinderella: Cinderella," "Snow White and the Seven Dwarfs". The study has tried to reveal in which way gender organizations have been formatted by examining the representation of feminity in "Cinderella: Cinderella," "Snow White and the Seven Dwarfs" fairy tales using the method of content analysis. It can be assumed that gender codes are learned at an early age, and in childhood they are narrated many times. Also the "Cinderella: Cinderella" and "Snow White and the Seven Dwarfs" fairy tales' research findings are important in terms of proving how the masculine-feminine identity code is structured in society.

Key Words: Sex, Gender, Tale, Cartoons, Content Analysis

\section{Giriş}

Tüm dünyadaki çocuklar sözlü ya da görsel olarak masallarla çok küçük yaşlarda tanışmaktadır. Bu masallar aile bireylerinden, çevrelerinden ya da medya aracılığıyla çocukların gelişimlerine katkıda bulunmaktadır. Onların hayal dünyalarının ve kişiliklerinin gelişmesinde çok önemli bir materyal olan masallar yüzyıllardan bu zamana kadar en yaygın olarak kullanılagelmiştir. Gerek içerdiği fantastik olaylar, kahramanlar, olay örgüsü gerekse anlatım tarzı ile çocukların her zaman ilgisini çekmiştir. 
Günümüzde her alanda yaşanan hızlı dönüşüm ve değişimin baş mimarlarından olan kitle iletişim araçlarından medya, çocukların yaşamlarında da önemli bir yer işgal etmektedir.

Çocukların ilgisini çeken bu renkli dünya onlar için daha cazip hale getirilmektedir. Gelenek ile modernitenin birleştiği bir alan olan masalların çizgi filmlere aktarılması çocukların bu alana olan ilgisini bir kat daha arttırmaktadır. Psiko-sosyal gelişimlerine katkıda bulunmak ve onları eğlendirmek amacıyla görselliğin daha etkin bir şekilde kullanıldığı masalları konu alan bu çizgi filmlerin sayıları günümüzde gittikçe artmaktadır. 2-5 yaş arası çocuk grubuna hitap eden bu masallar, sundukları görsel materyaller ile çocukların sosyalizasyonlarına katkı sağlamaktadır. Ebeveynler de bu çizgi film masallarını çocuklarına satın alarak ve izleterek çocuklarının toplumsallaşma sürecine bilerek veya bilmeyerek katkıda bulunmaktadırlar.

Bu anlamda toplumsal cinsiyete ilişkin inşa edilmiş kodların, masalları konu alan çizgi filmler üzerinden aktarımının incelenmesi eril tahakkümün örtük kodlarının keşfedilmesi açısından önem taşımaktadır. Bu nedenle araştırmamızda ilk olarak cinsiyet ve toplumsal cinsiyet kavramları ve bu kavramların kökenlerini konu alan bir tartışma başlatılmıştır. Medya ve masallara ilişkin başlığın ardından, araştırmanın konusu, amacı ve önemi belirtilerek araştırmamızda kullanılan metodolojik yaklaşım açıklanmıştır. Araştırmaya konu olan analiz materyallerinden elde edilen bulgular ve bu bulgulara ilişkin betimsel analizler bulgular başlığı altında sunulmuştur. Sonuç ve tartışma kısmında araştırma bulguları üzerinden yapılan analizler değerlendirilmiştir.

\section{Cinsiyet ve Toplumsal Cinsiyet}

Cinsiyet ve toplumsal cinsiyet kavramlarına ilişkin kesin bir ayrım yapabilmek ad1na kelimelerin epistemolojik kökenlerinin bilinmesi önem arz etmektedir. Cinsiyet (sex) kavramı bireyin kadın ve erkek olmasının biyolojik yönüne atıfta bulunurken; toplumsal cinsiyet (gender) ise toplum ve kültür tarafından yüklenen anlama atıfta bulunmaktadır (Deaux, 1987, s.372; Franzoi, 1996, s.67; Lips, 2001, s. 112). Kelime anlamı itibariyle de İngilizce'de "sex" Türkçede biyolojik anlamda kullanılagelen "cinsiyet" kelimesine, "gender" terimi ise Türkçede toplumsal inşa sürecine atıfta bulunan "toplumsal cinsiyet"e karşılık gelmektedir (Illıch, 1996, s. 26-27). Cinsiyet, anatomik yapının kader olduğu düşüncesinden hareketle biyolojik indirgemeciliği ifade etmektedir. Toplumsal cinsiyet ise biyolojik farklılığın toplumda inşa etmiş olduğu algı üzerinden gidilerek kadın ve erkek cinsinin ilişkiselliğine odaklanmaktadır. Hem biyolojik farklılık hem de ilişkiselliğin yarattığı çelişkiyi bir potada toplayan kadınlık ve erkeklik durumunun bir inşa olduğu noktasından hareketle, sürece ve devingenliğe göndermede bulunulmaktadır. Toplumsal cinsiyet rolleri bize kadın ve erkeğe ilişkin kalıp yargıların ve algıların nasıl inşa edildiği hakkında bilgi vermektedir. $\mathrm{Bu}$ farklı anlamlar toplum tarafindan bireylere belli kültürel ve toplumsal normlar dahilinde kazandırılmış kimliklerdir (Güzel, 2015, s. 509). Toplumsal cinsiyet, toplumsal örüntülerle asimetrik bir biçimde iç içe geçtiğinden ancak toplumsal yapı analizleri 
ile anlaşılabilmektedir (Alkan ve Çakır, 2012, s. 197-199). Bu bağlamda düşünecek olursak toplumsal cinsiyet kavramı, toplumun kurumları, grupları, sinıfları ve sosyo-kültürel ilişkileriyle makro ve mikro yapıların bir araya gelmesiyle oluştuğundan bu kavramları anlamak için bu yapıların nasıl oluştuğuna dair güçlü bir bilgiye sahip olmak gerekmektedir.

Toplumsal cinsiyete ilişkin roller ve tanımlamalar toplum tarafından belirlenmekte ve kadın ve erkeğe benimsemesi için sunulmaktadır. Bu sunuş hayatın her alanında kendini baskın bir şekilde hissettirmektedir. Toplumsal cinsiyet rolleri bireylere birtakım sorumluluklar yüklemektedir. Bireyin kişisel özellikleri, davranışları, algıları, motivasyonları, değerleri ve duyguları toplum tarafından oluşturulan söylemlerle şekillenmektedir (Lorber, 1994, s. 114; Scott, 2007, s. 11; Bilican Gökkaya, 2015, s. 237). Örneğin erkeğin evini geçindirmekle yükümlü görüşü, kadının ev içi işlerden sorumlu tutulması veya kız çocuklarının giysilerinin pembe tonlarında ve süslü olmas1 öğretilirken, erkekler de ise mavi ve pastel renkli sade kiyafetlerin tercih edilmesi bu durumun bir göstergesidir (Akın ve Demirel, 2003; Wharton, 2009, s.123; Çalışır ve Okur Çakıc1, 2015).

Toplum tarafından kadınların "narin, duygusal" erkeklerin ise "rasyonel" taraflarının olduğuna dair yanlış bir takım algılar bulunmaktadır (Bee ve Boyd, 2009, s. 93). Bu algı çerçevesinde kadın ve erkek arasındaki ayrım daha da derinleştirilmektedir. Bu algılar kadınlar üzerinde bir eşitsizlik unsuru oluşturmaktadır. Örneğin yönetici seçiminin olduğu bir şirkette kadın sadece "narin, duygusal" algısından dolayı yönetici olamamakta bu konuma bir erkek tercih edilebilmektedir. Bu "cam tavan" metaforu hayatın her alanında kadınların karşısına çıkabilmektedir.

Ataerkil söylemde eve bağımlı kadın imgesinin aksine erkeğin ise dışarı odaklı olması benimsenmektedir. Kadının ev işleriyle meşgul olması gerekirken erkek ise dışarıdaki işlerle meşgul olmalı, kadın eve bağımlı bir hayat sürerken erkek ise dışarıda özgür bir yaşam sürmektedir. Masallarda ataerkil sistemin bu geleneksel söylemlerinin etkisi kırılamamakta ve aksine bu durum evcil kadın ve özgür erkek imajları olarak yeniden üretilmektedir (Abisel, 1994, s. 54; Ekici, 2007, s. 87; Sezer, 2004, s. 96).

Ataerkil söylemlerin baskın unsur olduğu toplumlarda bağımsız kadın dışlanmakta, bağımlı kadın ise her zaman ödüllendirilmektedir. Bağımsızlık olgusu o kadar erkekle özdeşleştirilen bir kavram olarak kullanılagelmiştir ki kadın kendi ayaklarının üzerinde durdukça, kendi kararlarını aldıkça yani bağımsızlaştıkça "erkeksileştiği” düşünülmektedir. Toplumun baskın unsurları içerisinde şekillenen erkekler bağımsız kadını sevimsiz olarak nitelendirmektedir. Simone de Beuviore göre, "kadın-erkek ilişkileri keman piyano sonatına benzer mutlu olmak için kadın nerede öne çıacağını nerede arka planda kalacağını çok iyi bilmelidir" (1997, s. 21). Beauvoire göre, kadın karşılaştığı bu durum karşısında nasıl bir tercih yaparak hangi yolu seçeceğine karar veremez. Dolayısıyla bağımsız kadın bir kısır döngü içerisine girmiştir. Erkeğin otoritesinden çıkmak ama bağımsız bir kadın olup toplumun normları ile çatışmak. 
Bunun neticesinde toplum tarafından dışlanmak, yalnız kalmak ve kültürel kodlarla yetişmiş bir kadının yeniden bir erkeğe ihtiyaç hissetmesi ve bağımlı olarak hayatını yaşaması gerektiği döngüsünde sıkışıp kalmaktadır (1997, s. 3).

Dowling’e göre (1999, s. 7) günümüz toplumunda kadın aile içerisinde kabul görme, barınma sorunu yaşamaktadır. Kadın bu durumun üstesinden gelmek için kocasından daha fazla çalışması ve riske atılması gerektiği inancı yatmaktadır. Bu inanç bilinç düzeyinde mantıklı bir yer etmediğinden kadın bu inancını rasyonelleștirmek için, kocasını kendisinden daha yetenekli olduğuna inandırmaktadır. Böylelikle kadın kendisine diğer kadınlarla rekabet halinde olmadığı bir güvenlik alanı yaratmış olacaktır. Kadın kendisine yarattığı bu pasif rolü erkek üzerinde iktidar kurabilmenin yegâne aracı olarak görmektedir. Kadın, erkeğe verdiği "sana muhtacım" mesajı ile erkeğin gururunu okşamakta ve kendisinden ayrılmasını imkânsız kılmaktadır. Aynı zamanda erkeğe anne şefkati ile yaklaşması ile de bu özelliğini daha da güçlendirmektedir.

\section{Medya, Masallar ve Toplumsal Cinsiyet}

İletişim araçlarının günümüzde yaygınlaşması ile birlikte kitle iletişim araçları her yaş grubundan bireyin kolaylıkla erişebilmesini mümkün kılmaktadır. Bu araçların yaygınlaşması ile birlikte her yaş grubuna hitap eden yayınlar günün her saatinde kolaylıkla erişilebilir hale gelmiştir. Küçük yaş grubundaki çocuklara "dadılık" yapan bu kitle iletişim araçları ebeveynler tarafından kontrolsüz bir şekilde izlettirilmektedir. Çocuklar, karakter gelişimini sağladıkları kritik dönem olan 0-6 yaş döneminde subliminal mesajlara ebeveynler tarafından bilinçsiz bir şekilde maruz bırakılmaktadır. Aile içerisinde kitle iletişim araçlarına en çok maruz kalan bireylerin çocuklar (Şirin, 1999, s. 45) olduğu düşünüldüğünde konunun önemi bir kez daha ortaya çımaktadır.

Toplumsal cinsiyet ve medya ilişkisine bakıldığında toplumsal cinsiyetin sosyal öğrenme yoluyla çocuklar tarafından içselleştirildiği gündeme gelmektedir. Sosyalleşme aracı olan televizyonla beraber çocuklar aynı zamanda toplumsal cinsiyet temelli sunulan erkeklik ve kadınlık kalıplarını da öğrenmektedirler. Toplumsallaşma döneminin en kritik evresini medyadan aldığı bu kalıp yargılarla inşa eden bir çocuk kendisine empoze edilen ataerkil söylemlerden bağımsız düşünemeyecektir. Medya aracılığıyla sunulan rol modelleri içselleştirerek, hafızalarının en aktif olduğu bu dönemde bir daha unut(a)mayacak şekilde kodlayacaktır.

Toplum tarafından inşa edilen ve medya aracılığıyla baskın bir biçimde sunulan ataerkil söylem sadece kadınları değil aynı şekilde erkekleri de belirli kalıplara sokmaktadır. (Connel, 1998, s. 254; Türmen, 2003, s. 5). Feminist kuramcılara göre, medya patronları ve yapımcılarının büyük bir çoğunluğu erkek olduğundan dolayı bu alanda erkek egemenliği bulunmaktadır ve ürettikleri argümanlar ataerkil toplumun çıkarlarına hizmet etmektedir. Buna karşın feminist kuramcılar yine toplumda bulunan baskın düşünceleri değiştirmenin yolunun bu duruma sebep olarak gösterilen medya 
aracılığıyla olacağını savunmuşlardır (Zoonen, 1997, s. 476). Medya programlarının eleştirel bir gözle izlenmesi cinsiyetçiliğe karşı toplumsal bir bilinç oluşmasını sağlayacaktır.

Diğer edebî metinler veya kültürel unsurları barındıran ürünlerle kıyaslandığında masalların kaynağı da sözlü halk geleneğine dayanmaktadır. Göçgün’e göre ilk olarak ilkel kavimlerde sözlü biçimlerde ortaya çıkan masallar daha sonraki dönemlerde gelişerek güzelleşmiştir. Ayrıca masallar halk anlatmalarının en çok ilgi gören türlerinin başında gelmektedir. Bir masalın tarih sahnesinden silinip gitmemesi veya yaşaması, halk tarafından kabullenilmesine ve içselleştirilip nesilden nesle aktarılmasına bağlıdır. Bu aktarım sürecinde masallar birçok kültürel kodun nesiller boyu devrini de sağlamaktadır (Göçgün, 2004, s. 131). Diğer bir ifade ile masal, içinde bulunduğu toplumun normlarının, stereotiplerinin, baskın düşüncelerinin, örtük kodlarının ve kültürel unsurlarının yeniden üretiminde etkin bir rol üstlenmektedir. Özellikle çocukların yetişmesinde önemli bir argüman olarak kullanılagelen ve toplumun tarafından masum bir eğitim ve eğlence aracı olarak kabullenilen masal, toplumlarda kültürel dinamiklerin yeniden üretilmesinde ve yerleştirilmesinde önemli bir araç olarak kullanılan kültür aygıtlarının başında gelmektedir. Ortak bilinçdışımızın şekillendirilmiş ve resmedilmiş bir ürünü olarak masallar (Saydam, 1997, s. 46) kendi simgesel anlamının ötesinde inşa edilmiş kolektif bir bilinçdışının varlığının bir göstergesidir (Junk, 1996, s. 51).

Bir birey olarak kolektif bilinçdışı dünyamızın inşası ilk olarak çocukluk döneminde başlamaktadır. Bu dönem aynı zamanda bireysel kimliklerimize ait kodlarımızın toplumsallaşma aracılığı ile inşa edildiği dönemdir. Bu dönem bireyin bir başkasına benzemek amacıyla başka bireylerle özdeşleşme kurduğu dönemdir. Öznel anlamda “ötekileştirilmiş benlikler” ile özdeşleşmenin bir sonucu olarak kişiliğe ait kodlar inşa edilmektedir (Hans, 2006, s. 278; Dewey, 1996, s. 133; Hall, 1998, s. 71). Bu bağlamda masallardaki karakterleri kendisi ile özdeşleştirmeye çalışan çocuklar, masallar yoluyla cinsiyet rollerine ilişkin kalıp yargılarla karşı karşıya kalmaktadırlar (Yağan Güder, 2014, s. 16). Kişiliğin ve karakterin gelişiminde okul öncesi dönem olan 0-6 yaşın önemi düşünüldüğünde, masallardaki toplumsal cinsiyet rolleri ile kurulan özdeşimin çocukların ruhsal gelişimlerinde son derece etkili olduğu daha kolay fark edilecektir.

Okul öncesi yaş grubundaki çocuklar üzerinde yapılmış bir çalışmada, bir hafta içerisinde kız çocuklarının 12,5 saat, erkek çocuklarının ise 13,5 saat televizyon izledikleri bulgusuna ulaşılmıştır (Dennison, Russo, Burdick ve Jenkins, 2004, s. 173). Çocukların televizyonda en çok neyi seyrettiklerini konu alan çalışmalarda; çocukların en çok çizgi film izlemeyi tercih ettiği tespit edilmiştir (Cihangir ve Demir, 2003, s. 143; Yıldırım, 2008, s. 126). Bir başka çalışmada, çocukların televizyonda en çok neyi izlemekten hoşlandıkları sorusu sorulmuştur. Alınan cevaplarda ise çizgi filmlerin \% 41,6 ile birinci (Cesur ve Paker, 2007, s. 121) sırada geldiği dikkati çekmiştir.

Propp çalışmasında masalların aynı parçalar üzerine kurulduğunu, kişilerin adları ve 
nitelikleri değişmesine rağmen eylemleri ve işlevlerinin sabit olduğunu ortaya koymuştur.

Propp’a göre masallardaki değișen unsurlar fantastik olaylar ya da nesnelerdir ancak arkadaki kişilik özellikleri değişmez. Bu anlamda masallar karakterler üzerinden değil “prototip”ler üzerinden ilerlemektedir. Bu haliyle masallar öğretilerini bilinçaltında, fark edilmeyen; bu nedenle de uğraşılmayan bir mekanizmayla işletmektedir (Propp, 2001, s. 87).

Masallarda kullanılan dil toplumsal cinsiyet açısından kadın ve erkek ayırımını pekiştirmekte, aynı zamanda çocukların karakterine yönelik olarak hangi karşıtlık üzerinden yapılandırılması gerektiğini de vurgulamaktadır. Masallarda sunulan iyi-kötü, güzel-çirkin gibi ikili dikotomilerle çocukların hangi rol modeli seçeceği büyük ölçüde belirlenmektedir (Sezer, 2010, s. 22). Bu bağlamda masalları konu alan çizgi filmlerde yansıtılan karakterler ve kullanılan dil ile ikili zıtlıklar oluşturulurken, zıtlıklar arasında kalan gri bölge olarak görülen yumuşak geçişlere yer verilmemekte, karakterler siyah ve beyaz olarak net çizgilerle ayrılmaktadırlar. Daha belirgin bir örnekle, kötü kadın rolündeki kötü kalpli kraliçeler siyah renk ile bütünleşmiş iken güzelliği ve masumluğu ile ön planda olan prensesler ise beyaz renk ile temsil edilmektedir. Böylelikle çocukların karakterler arasında seçim yapması güdümlü bir şekilde sağlanmaktadır. Beyaz tonlar ile temsil edilen masum prensesler ataerkil topluma ait basmakalıp normlarla hareket etmektedirler. Masal anlatısında kurgulanan bu diyalektikte çocukların rol model alarak özdeşleşmek istedikleri karakterler, ataerkil toplum düzeninin normlarına karşı gelmeyen, otoriteye boyun eğen karakterler iyi ve güzel olanlardır. Masallarda sunulan bu ayrımların renkler ve şekillerle belirlenmesi çocukların iradeleri ile kahramanlar arasında seçim yapmalarına engel olmaktadır. Gizil bir yönlendirme ile çocukların hangi kahramanla özdeşleşeceği dayatılmaktadır.

\section{Araştırmanın Konusu, Amacı ve Araştırma Problemleri}

$\mathrm{Bu}$ araştırmanın konusu, sosyal bir aktör olarak bireyin sosyalleşmesi ve toplumsallaşmasında bir dönem olan çocukluk dönemine ait çocuk çizgi filmlerindeki masalların içerik çözümlenmesini teşkil etmektedir. Çocuk masallarını konu alan çizgi filmlerin, toplumsal cinsiyetin açık ve örtük kodları ve biçimlerini temsil etmede ve aktarmadaki zenginliğinin verimli bir kaynak teşkil edeceği araştırmacılar tarafından değerlendirilmiştir.

Günümüzde sinema sektörünün gelişen teknoloji sayesinde hitap ettiği hedef kitle ve etki alanı daha da artmıştır. Bu durum bir sosyal aygıt olarak sinemanın ataerkil düzene ait kodların yeniden üretilmesi ve inşa edilmiş toplumsal cinsiyet kodlarının aktarılmasındaki etkinliğini daha da arttırmıştır. Bu nedenle bu araştırmada toplumsal cinsiyet kodlarının bir aktarım aracı olarak kullanıldığı "Külkedisi: Sindirella", "Pamuk Prenses ve Yedi Cüceler" adlı çizgi filmlerde toplumsal cinsiyet kodlarının hangi biçimlerde işlenildiği ve çözümlemesi bu çalışmanın konusunu oluşturmaktadır. 


\section{Araştırmanın Amacı}

Bu çalışma ile "Külkedisi: Sindirella”, "Pamuk Prenses ve Yedi Cüceler" masallarında yapılandırılan kadınlık temsillerinin irdelenerek, toplumsal cinsiyet organizasyonunun ne şekilde biçimlendirildiğinin ortaya konulması amaçlanmaktadır. Toplumsal cinsiyete ilişkin kodların erken yaşlarda öğrenildiği kabulünden hareket edildiğinde; çocukluk döneminde defalarca anlatılan ve aynı zamanda bu araştırmanın da konusu olan "Kül Kedisi: Sindirella" ve "Pamuk Prenses ve Yedi Cüceler" adlı masallarda çocukların bilinçaltına nelerin işlendiği ve toplumdaki eril ve dişil kimliklerin en baştan nasıl şekillendirildiğini ortaya koymak açısından bu araştırma bulgularının keşfedilmesi önem arz etmektedir.

\section{Araştırma Problemleri}

Araştırmanın temel amacı doğrultusunda, çözümlenecek olan materyalde aranacak cevaplara yönelik belirli bir sistem dahilinde problem cümleleri oluşturulmuştur. Böylece toplumsal cinsiyetin yeniden üretilmesinde masalların hangi biçimlerde işlendiğinin ortaya konulması amaçlanmıştır.

Temel Problem Cümlesi: Pamuk Prenses ve Yedi Cüceler, Külkedisi: Sindirella masallarında toplumsal cinsiyet kodları, toplumsal cinsiyet organizasyonu, kadınlara toplumsal anlamda atfedilmiş rol örüntüleri nasıl kurgulanmıștır?

1. Alt Problem Cümlesi: Toplumsal cinsiyet materyal içinde nasıl konumlandırılmıştır?

2. Alt Problem Cümlesi: Materyal bünyesinde cinsiyetlendirilmiş kadınlık toplumsal rolleri, kadınlık temsilleri üzerinden nasıl sunulmaktadır?

3. Alt Problem Cümlesi: Toplum tarafından kadına atfedilen "güzellik" imgesi materyal üzerinde hangi biçimlerde temsil edilmektedir?

4. Alt Problem Cümlesi: "İtaatkâr kadın” prototipi materyalde nasıl işlenmektedir?

5. Alt Problem Cümlesi: Kadındaki "bağımsızlık korkusu” hangi egemen değerler üzerinden materyalde yansitılmaktadır?

6. Alt Problem Cümlesi: Kadına atfedilen “duygusallık” imgesi materyalde nasıl inşa edilmekte ve hangi kalıp yargılarla izleyiciye sunulmaktadır?

7. Alt Problem Cümlesi: Kadın korkusu toplumsal cinsiyet bağlamında nasıl ele alınmış ve materyaldeki yansımaları nelerdir? 


\section{Yöntem}

Bu bölümde araştırmanın modeli, örneklemi, verilerin toplanması ve analizi ile araştırmanın analiz materyallerine ilişkin bilgilere yer verilmiştir.

\section{Araştırmanın Modeli}

Çalışmanın metodoloji tercihi incelenecek materyallerin türü ile şekillendirilmiştir. Materyalin en etkin bir şekilde nitel analizinin yapılması, tanımlanan amaçlar doğrultusunda oluşturulan kategorilerin açıklanmasında belirleyici bir rol oynamıştır. Araştırma deseni olarak nitel desenin kullanılmasındaki bir diğer neden de nitel araştırmanın doğasından kaynaklanan; "gerçeğin sosyal olarak inşa edildiği" fikridir (Merriam, 2013, s. 8). Öznel deneyimlerle inşa edilmiş gerçekliklerin ve bu gerçekliklere atfedilmiş anlamların keşfedilmesi ise araştırmacıyı araştırma yapmaya yöneltmektedir (Cressell, 2007, s. 63).

$\mathrm{Bu}$ amaçla nitel araştırma perspektifi ile yapılan bu araştırmada toplumsal cinsiyet organizasyonunun irdelenmesi amacı ile içerik analizi tekniği kullanılmıştır. Analiz biçimi olarak içerik analizi tekniğinin seçilme nedenlerinden biri; içerik analizinin "gazeteler, dergilerin kapsama eğiliminde olduğu konular ile başyazarların ideolojik yönünü, uzun metrajlı filmlerdeki basmakalıp cinsiyet rollerini..." (Neuman, 2011, s. 467) ortaya çıkartmak için kullanılabilir olmasıdır Bir diğer neden ise içerik analizi tekniği ile araştırmacının bir iletişim kaynağındaki (film, dergi, gazete vb.) içeriği, anlamı ve örtük mesajları açığa çıkartmasına imkân sağlamasıdır (Neuman, 2011, s. 466).

\section{Örneklem}

Masalları konu alan çizgi filmleri gibi geniş bir evren söz konusu olduğunda, bu çizgi filmlerin yapım yılı, menşei, süresi vb. ölçütlerce birçok kategoride sınıflandırma yapılabilmektedir. Bu bağlamda araştırmamızda örneklem seçiminde ise amaçlı örneklem seçimi tekniği kullanılarak, "Kül Kedisi: Sindirella" ve "Pamuk Prenses ve Yedi Cüceler" adlı masalların çizgi filmleri örneklem olarak belirlenmiştir. Bu çalışmada örneklemi belirlemek maksadıyla amaçlı örneklem tekniği kullanılmıştır. Amaçlı örneklem tekniği, belirli örnek olay türlerini derinlemesine incelemek için belirlemek istendiğinde kullanılan bir yöntemdir (Neuman, 2011, s. 324).

\section{Verilerin Toplanması ve Analizi}

$\mathrm{Bu}$ amaçla, içerik analizi yöntemi kullanılarak incelenen çizgi filmler, tanımlanan problem cümlelerine aranacak cevaplar bakımından ön izlemeye tabi tutulmuş ve buna göre temel kategoriler şekillendirilmiştir. Kategoriler, filmin teması, sahne yoğunluğu ve sıklığ1 gözetilerek oluşturulurken, diğer yandan kavramsal ve kuramsal çerçevenin sağladığı kavram setleri ile desteklenmiştir.

Verilerin analizi aşamasında literatür taraması yapılmış ve kuramsal çerçeveye dayalı 
araştırma soruları oluşturulmuştur. Bu araştırma soruları çerçevesinde çizgi filmler izlenmiş ve veri azaltma yöntemine gidilmiştir. Veri azaltma yöntemiyle araştırmamızın konusu dahilinde olabilecek sahneler belirlenmiştir. Belirlenen bu sahneler tekrar izlenmiş, araştırma soruları ekseninde kurama ve örnekleme dayalı kategoriler eş zamanlı oluşturulmuştur. Kategorilerin kapsayıcı olduğu göz önünde bulundurularak, detaylandırılarak örnekleme uygun olarak alt kategoriler belirlenmiştir. Masallar araştırma soruları ve alt kategoriler ekseninde incelenmiştir. Kategorilerin belirgin olduğu sahneler tekrar izlenerek kuramsal çerçevede literatürden de desteklenerek yorumlamalar yapılmıştır.

\section{Araştırmanın Analiz Materyalleri, Türü ve Tanımlayıcı Bilgileri}

Resim 1. http://disneyturkiye.com.tr/ adlı internet sitesinden alınmıştır.

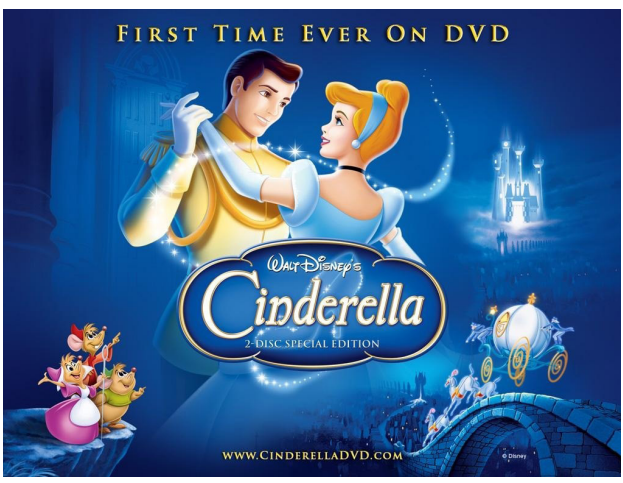

\begin{tabular}{|l|l|l|}
\hline \multirow{2}{*}{$\mathbf{1}$} & Materyalin Adı & Külkedisi: Sindirella \\
\cline { 2 - 3 } & Materyalin Orijinal Adı & Cinderella \\
\cline { 2 - 3 } & Süre & 74 Dakika \\
\cline { 2 - 3 } & Ülke & Amerika \\
\cline { 2 - 3 } & Yapım Şirketi & Walt Disney \\
\cline { 2 - 3 } & Yazar & Charles Perrault \\
\hline
\end{tabular}




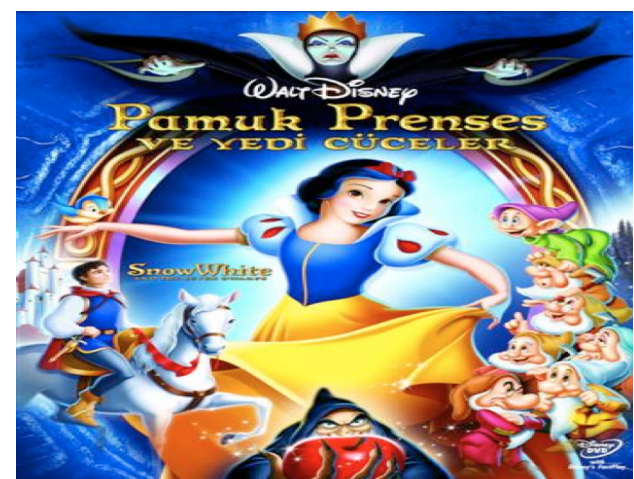

Resim 2. http://disneyturkiye.com.tr/ adlı internet sitesinden alınmıştır.

\begin{tabular}{|c|c|c|}
\hline \multirow{6}{*}{2} & Materyalin Adı & Pamuk Prenses ve Yedi Cüceler \\
\hline & Materyalin Orijinal Adı & Snow White and the Seven Dwarfs \\
\hline & Süre & 91 Dakika \\
\hline & Ülke & Amerika \\
\hline & Yapım Şirketi & Walt Disney \\
\hline & Yazar & Grimm Kardeşler \\
\hline
\end{tabular}

\section{Bulgular ve Yorumlar}

Bu bölümde içerik analizi yöntemi sonucunda oluşturulan kategorilere (temel kategoriler ve alt kategoriler) ve verilerin analizi sonrasinda elde edilen bulgulara yer verilmiştir.

\section{Kategoriler}

Elde edilen bulgular neticesinde araştırma problemleri ile ilgili altı temel kategori ve bu kategoriler ile ilişkili alt kategoriler belirlenmiştir. 
Tablo 1: Temel ve Alt Kategoriler Tablosu

\begin{tabular}{|l|l|}
\hline Temel Kategoriler & Alt Kategoriler \\
\hline Kadının Güzellik İmgesi & $\begin{array}{l}\text { Zayıflık, Gençlik, Narin, Masum güzel, Bakım- } \\
\text { lı, Zarif, Güzel giyim, Güzel, En güzel, Çekici- } \\
\text { lik, Bekâret, Koşulsuz fiziksel güzellik. }\end{array}$ \\
\hline Eve Bağımıı Kadın İmgesi & $\begin{array}{l}\text { Mekân olarak ev, Ev işleriyle ilgilenmek, Hiz- } \\
\text { met etmek, Hizmetçilik, Beceriklilik, Yabancı- } \\
\text { larla konuşmamak, Vaktinde eve dönmek, Eve } \\
\text { bağlılık, Ev içi roller. }\end{array}$ \\
\hline $\begin{array}{l}\text { İtaatkâr Kadın ve Erkeğin Sor- } \\
\text { gulanamaz Otoritesi }\end{array}$ & $\begin{array}{l}\text { Acıya alışmak, İtaatkâr kadın, Otoriter erkek, } \\
\text { Erkekten izin almak. }\end{array}$ \\
\hline Kadının Bağımsızlık Korkusu & $\begin{array}{l}\text { Bağımsızlık korkusu, Yalnız kalma korkusu, Bi- } \\
\text { reysel olarak hayatını idame ettirememe, Baş- } \\
\text { kalarına muhtaç yaşama. }\end{array}$ \\
\hline Kadına Atfedilen Duygusallık İmgesi & $\begin{array}{l}\text { Narin, Duygusal, Erkek mantıklılığı, Anaç, } \\
\text { Pembe düş, Rüya, Ağlamak, Merhamet, Seve- } \\
\text { cenlik. }\end{array}$ \\
\hline Kadın Korkusu & $\begin{array}{l}\text { Kadın nefreti, Kadın düşmanlığı, Üvey anne, } \\
\text { Cadı, Baştan çıkarıcı, Cazibeli, İkinci evlilik, } \\
\text { Rekabet, Büyücü, Kötü kadın, Kıskançlık. }\end{array}$ \\
\hline
\end{tabular}

Temel Kategori 1: Kadının Güzellik İmgesi:

Resim 3: Sindirella Uyanırken

Sindirella sabah uykusundan henüz uyanmasına, daha yataktan çıkmamasına ve yamalı battaniyesine rağmen fiziksel güzelliğinden ödün vermemesi, saçları düzgün bir şekilde yapılmış, dudakları rujlu, tırnakları bakımlı olması dikkat çekmektedir (03:02) (Bkz. Resim 3). Günümüzün popüler bakımlı, güzel kadın imaj göster-

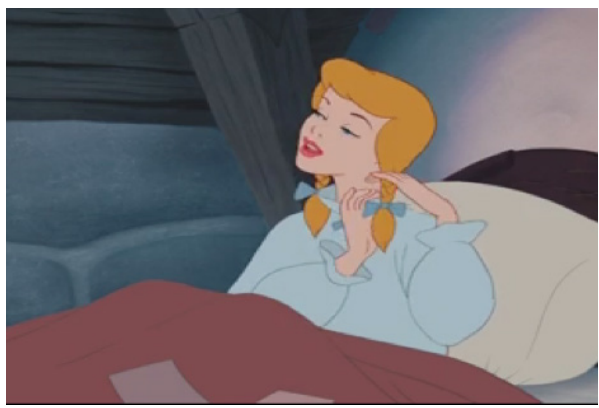
gesi olarak sarışın mavi gözlü olarak resmedilmiştir (masum güzel, gençlik, bakımlı, zarif).

Pempe düşler kuran Pamuk Prenses'in kraliçe annesi "keşke benim de böyle kan gibi kırmızı dudaklı, kar gibi beyaz tenli siyah saçlı bir kızım olsa...” (01:02) diyerek istediği kız profilini sadece güzellik üzerinden kurgulamakta; masalın başında tasvir edilen Pamuk Prenses de yine güzellik üzerinden bir betimleme yapılarak tasvir edilmekte, kişiliği ile ilgili herhangi bir tanımlamaya gidilmemektedir; "dudakları gül kırmızı, saçları abanoz siyahı, teni pamuklar gibi..." (03:11) (gençlik, güzellik, bakımlılık). Aynı şekilde cücelerin Pamuk Prenses'i evlerinde ilk gördüklerinde "çok tatlı, çok güzel, tıpkı bir melek gibi” (33:40) tanımlamasını yapılmaktadır. 
Resim 4. Sindirella Temizlik Yaparken

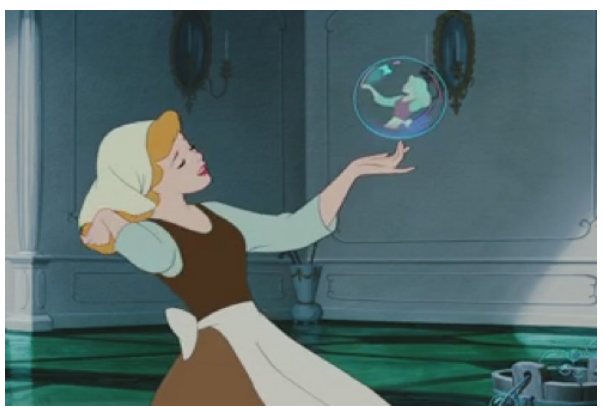

Sindirella sürekli bakımlı ve güzeldir, evde hizmetçilik yaptığı zamanlarda dahi sabun köpüklerine bakarak kendini izler ve saçını, başını düzelterek güzelliğini kontrol etme ihtiyacı hisseder (27:01) (Bkz. Resim 4). Güzellik takıntısı giyilen elbiselere de yansımış görünmektedir. Sindirella masalında üvey kardeşlerin baloya gideceği elbiseyi seçerken yaşadığı kararsızlık ruhsal bunalıma varacak derecede şiddetli sunulmuştur (40:45). Elbiselerin içinden sürekli daha güzel elbiseyi bulma gayreti, bulunan elbiseleri sürekli beğenmemeleri en güzelini istemeleri, Sindirella’ya perinin verdiği elbise sonrasında: “...Güzel bir elbise ve cam ayakkabılar daha önce hiç görülmemiş kadar güzel ve cüretkâr bir elbise...” (47:02) sözü de beden güzelliğinin yanında kıyafete de önem verilmesine vurgu yapmaktadır.

Resim 5. Pamuk Prenses Çiçek Toplarken

Pamuk Prenses'in ormana çiçek toplamaya giderken bile giydiği kıyafet davette giyilecek gece kıyafeti kadar şık ve bakımlıdır (Bkz. Resim 5) (zayıflık, gençlik, güzellik, bakımlılık, güzel giyim).

$\mathrm{Bu}$ masallarda işlenen en baskın unsurların başında kadının güzel ve bakımlı olması gerektiğidir. Kadın toplumsal hayatta

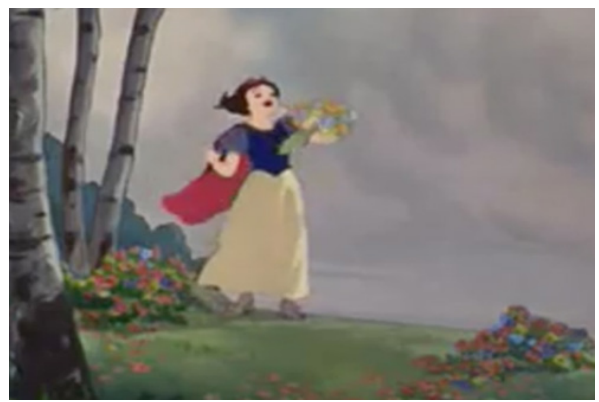
kabul görmek ve saygın bir konuma sahip olmak istiyorsa hayatın her alanında ve her zaman "bakımlı olmak zorunda"dır. Aksi bir durum, Sindirella’nın üvey kardeşlerinde olduğu gibi erkekler tarafından beğenilmemeye ve seçilmemeye mahkum olarak "evde kalmış" bir biçimde yaşamını sürdürmeye mahkum olacaktır. Bu durumu yeniden üreten bir sahne olarak; baloya davet edilen Sindirella’yı ilk görüşünde prensin sözü şu şekildedir: "Daha adınızı bile bilmiyorum fakat sizinle evlenmek istiyorum...” (54:02). Prens Sindirella'yı ilk defa görmesine, onun kişilik özelliklerine dair en ufak bir bilgisinin olmamasına ve adını dahi bilmemesine rağmen onunla evlenmek istemektedir. Prens, Sindirella ile evlenme kararını yalnızca onun fiziksel çekiciliğine bağlı kalarak vermiştir ve başka bir özelliğine bakma ihtiyacı duymamaktadır. Prens, Sindirella’nın balo salonuna ilk girişinde ondaki güzelliğinden etkilenmiş, adeta büyülenmiş ve onun evleneceği kız olduğunu saptamıştır. Bu durum ise masaldaki dış sesin şu ifadesiyle gösterilebilir: “... Prens, Sindirella’yı salona girer girmez fark 
etmiş. Bu güzel kızın beyaz bir güvercine benzeyen ellerine, ay gibi parlayan tertemiz yüzüne hayran kalmış. Onun, evlenmek için aradığı kız olduğunu hemen anlamış. Gidip Sindirella’nın yanına 'benimle dans eder misiniz?’ diye sormuş...” (51:04) (güzellik, zariflik, bakımlılık, güzel giyim, narin). Bu analizlerde ataerkil yapının baskın unsur olduğu toplumlarda kadının kişilik yapısı, karakteri gibi özelliklerinin erkekler tarafından hiçbir öneminin olmadığı gibi, onları erkekler gözünde değerli kılan asıl unsurun ise fiziksel güzellik olduğu ortaya çıkmaktadır. Kadına atfedilen değer beden imgelemi üzerinden sunulmaktadır ve kadın bedeni metalaştırılmaya açık bir araç olarak kabul edilmektedir.

Masallarda gösterilen fiziksel ve kişilik özellikleri olarak çirkin ve sevilmeyen karakterler kötü yürekli kadınlardır. Fiziksel açıdan güzel olanlar ise masumdur ve kişilik özellikleri itibariyle de güzeldir. Sindirella masalındaki üvey kardeşler bu duruma bir örnektir: Üvey kardeşler çirkindir ve Sindirella’ya sürekli kötü davranışlarda bulunmaktadırlar. Sindirella ise kardeşlerinin tam zıddı özelliklere sahiptir ve narin, zayıf bir fiziksel yapısı olduğu masalda sürekli vurgulanmaktadır. "Evlenilecek kadın” olabilmek, erkekler tarafından kabul görebilmek için rejim yapmanın şart olduğu, Sindirella masalında tekrarlanmaktadır. Prens tarafından evlenmek maksadıyla düzenlenen ve ülkenin dört bir tarafındaki güzel kızların davet edildiği baloya katılabilmek için üvey kardeşler hemen sıkı bir rejime başlarlar (30:13). Bu duruma anneleri de destek vermekten daha fazlasını yapmakta ve kardeşler arasında rekabet oluşturmayı amaçlamaktadır. Burada güzel olmanın yeterli olmadığı "en güzel” olmak gerektiği; ancak bu şekilde toplum tarafından kabul görülebileceği ve bunun da kardeşler arasinda rekabete varabilecek kadar meşru bir durum olduğu ideolojisi yaratılmaya çalışılmıştır. Bu durum masal içerisinde şu şekilde anlatılmaktadır: "Haydi yavrularım sizleri göreyim birinizden birisi mutlaka baloda Prensin gönlünü çalsın...” (30:24). Balo başladığında üvey kardeşler en güzel giysilerini giyer, makyajlarına özen gösterir ve süslenip baloya giderler. Baloya davet edilen kitlenin de "en güzel genç kız" niteliğine sahip olması gerektiği dikkat çekmektedir. Bunu masaldaki dış sesin anlatımından çıkarabiliyoruz: "Bir gün bütün bir ülkeye haber yayılmış. Kral, sarayında büyük bir balo veriyormuş. Bu baloya ülkenin bütün bayanları, özellikle güzel genç kızları davetliymiş. Çünkü kralın evlenme çağındaki oğlu, eşini baloya gelen genç kızlar arasından seçecekmiş...” (25:15) (güzel, en güzel, bakımlı, zayıf, güzel giyim, gençlik, çekicilik). Topluma empoze edilmiş bu stereotipler kadının güzelliğini ve çekiciliğini gençlik ile eşdeğer görmekte, kadının yaşlandıkça çirkinleşeceği, dolayısıyla sürekli genç görünmesi gerektiği algısı oluşturmaya çalışmaktadır. Modern toplum yapısında kişilik, karakter konusunda yeterli bilginin bulunmadığı durumlarda, kadın ne kadar düzgün fizikî bir yapıya sahip ve genç ise toplum içerisinde kabul görmesi de aynı oranda kolaylaşabilmektedir. İnşa edilmiş toplumsal cinsiyet kalıplarından karakter veya kişilikten ziyade algılanan estetik değer ön plana çıkartılarak yüceltilmektedir.

Bu tarz dayatmalarla yaşlılık içeriği ve tanımlaması da değişebilmekte ve kadınların yaşlılıkla ilgili korkular geliştirmesine neden olabilmektedir. Pamuk Prenses masalında genç kalmakla ilgili tutkuya sahip olan ve bunu bir takıntı haline getirerek ik- 
sirlerle, büyülerle gençliğini korumaya çalışan ise kötü kadın karakteri olan Pamuk Prenses'in üvey annesidir. Bu üvey anne genç kalma pahasını kendi kızını öldürmeyi göze alacak derecede Pamuk Prenses'in güzelliğini kıskanmaktadır. Güzel olmak bu masalda baskın unsur olarak kullanılmasına rağmen izleyiciye üvey anne ile kızı arasındaki yaş farkı hissettirilmeden bu rekabet meşru bir durum olarak sergilenebilmektedir. Ahıska’ya göre, "Hep genç olmaya çalışmakta gençliği fetişleştirici bir yan vardır. Gerek kültür yoluyla olsun gerek müstahzarlarla, böyle bir durumda gençlik artık o kişiye ait bir şey değil. Dışarıdan eklenen, sürekli biçimlendirilen ve taşınan bir şey" (1999, s. 11) haline gelmektedir.

Örneklemimizde masallardaki kadınlar güzellik açısından masum ve zeki güzel olmak üzere iki kategoriye ayrılmaktadır. Pamuk Prenses ve Sindirella masalının ortak özelliği masum güzelin yaptığı iyiliklerinin karşılığını masalın sonunda aldığı ve mutlu sona ulaşmış olmasıdır.

Resim 6. Kraliçe (Pamuk Prenses'in Üvey Annesi) Ayna Karşısında

Kötü kadın (Bkz. Resim 6) (çekici, baştan çıkarıc1, kötü ruhlu, tuzağa düşürücü kadin) olarak resmedilen kadın karakteri ise yaptıklarının cezasını hayatının geri kalanına mutsuz olarak devam ederek veya ölümle çekecektir. Örnek olarak Pamuk Prenses'in üvey annesinin uçurumdan aşağ 1 düşmesi ve ölümle sonuçlanması (81:02). Çünkü ataerkil düzende zekâ ve güzellik kavramlarının aynı kadında bu-

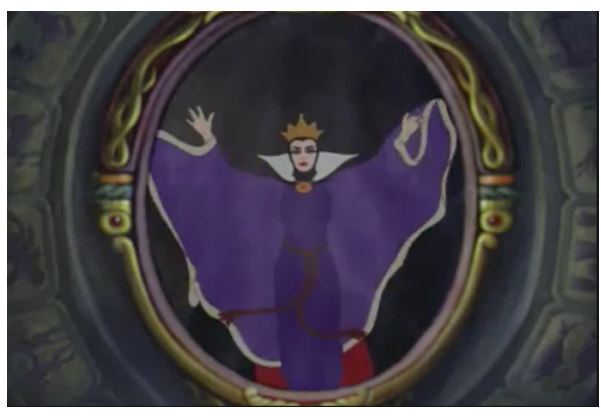
lunması kadının özne olarak konumlandırılmasının ve iradesini kullanabilmesinin bir göstergesi olarak algılandığından bu masallarda masum güzeller her zaman mutlu sonla ödüllendirilirler. Çalışmamızdaki bu iki masalda da kötü kadınlar cadı kadın olarak yansıtılmaktadır.

Resim 7. Cüceler Pamuk Prenses’i Tabutun İçinde İzlerken

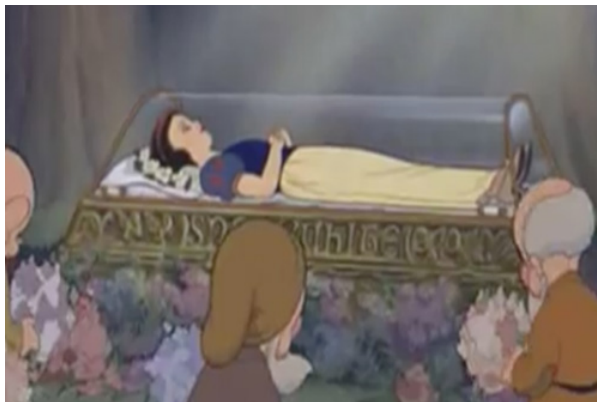

Kadınlardaki güzellik imgesi bir başka sahnede şu şekilde anlatılmaktadır: "Ölen Pamuk Prenses için ağıtlar yakan cüceler onu mezara gömmeye kiyamazlar, camdan ve altından mezar hazırlayıp güzelliğini seyretmeye başlarlar...” (40:02) (Bkz. Resim 6) (gençlik, güzellik, bakıml, güzel giyim, çekicilik). Bu sahnede dikkat çeken unsurlardan bir tanesi tabutun camdan yapılmış olması bunun tek amacının Pa- 
muk Prenses’in güzelliğini seyretmek olduğudur. Buradaki güzellik vurgusu o kadar çarpıcı ve mübalağalı bir şekilde anlatılmaktadır ki, ölü bir insanın bile güzelliği seyredilmeye değer kılınmaktadır.

“İlk öpücük” metaforunun kullanıldığı, Pamuk Prenses’in prens tarafindan öpülme sahnesinde de prenses prens tarafından ilk defa öpülmesiyle hayata döner ve bu öpücügün sebebi "erkeğin sevgisi değil kızın güzelliği”dir. Bu sahnede cam tabut cinselliğin muhafazası metaforunda kullanılsa da cam muhafaza "görselliğin vazgeçilmezliği; görmenin ama dokunamamanın, ulaşamamanın başka bir boyuttaki ifadesidir". Bu sahne Sindirella'da kullanılan ve masalın kilit metaforlarından biri olan cam ayakkabı ile aynı anlamdadır ve güzelliğin teşhirinde bir araç unsur olarak kullanılmıştır. İkincil bir değerlendirme olarak, cam tabutun "bekârete" yani "saf ve temiz olmaya" yaptı̆̆ bir atıf bulunmaktadır. Bunlara ek olarak cam tabut, Pamuk Prenses'in daha önce yaşadıklarının son bulması ve yepyeni bir hayata başlaması anlamını da taşımaktadır (Sezer, 2004, s. 12) .

Pamuk Prenses masalındaki bu sahnede dikkat çeken unsurlardan bir tanesi ölünün öpülmesidir. Normal şartlarda ölünün öpülmesi dehşet verici bir eylem olarak toplum tarafından algılanması gerekirken bu durum güzelliğinin ön plana çıkarıldığı prensese yönelik yapıldığından masum bir eylem olarak gösterilmiştir. Başka bir bakış açısıyla, prensesi ancak onun statüsüne denk bir prens öpebilir ve her ikisi de sinıfsal konumlarını korurlar. Prenses ise prens tarafından öpülür, yeni hayatına döner ve gözlerini açtığında ise kendisinin rızası olmadan bedenine yapılmış olan bu müdahaleye prense aşık olarak karşılık vermektedir. Sonuç olarak burada iki ihlal bulunmaktadır: Bir, prensesin rızası olmadan öpülmesi ve iki öpüşmenin cinsel birleşme simgesi olarak kurgulandığı göz önünde bulundurulduğunda ise bekâretin kaybolması (Sezer, 2004, s. 15$).^{5}$

Masalda Sindirella'nın baloda giydiği cam ayakkabılar o kadar küçüktür ki tüm ülkenin kızları tarafından denenmiş olmasına rağmen kimsenin ayağına uymamaktadır (62:00). Bu eşsiz ve ufak ayaklar aynı zamanda Sindirella'nın sahip olduğu güzelliğin bir göstergesidir.

Güzellik takıntısı kadınların erkeklere bakışında yine fiziksel bir imajdan yola çıkılarak yakışıklılık üzerinden kurgulanmıştır. Pamuk Prenses'in cücelere anlattığı masalın (aslinda Pamuk Prenses'in kendi hayalidir) sonunda “...Pamuk Prenses uzun boylu, güçlü yakışıklı bir prense aşık olmuş...” (51:18) sözüyle prensin de fiziksel güzelliğine vurgu yapılmış, Sindirella'da ise katıldı̆̆ bile daha yakışıklı değildir...” (56:00) sözü ile balonun başından sonuna kadar birlikte olduğu kişinin kim olduğunu ve adını bilmeden birlikte zaman geçirebildiği, dans edip, öpüştüğü halde bütün bunların olmasında fiziksel olarak beğenmesinin yeterli

5 “Onu bu ölüme sürükleyen -ailenin mirası olan- üvey annedir ve prensin öpücüğüyle aitlik ilişkisinin değişmesinin ardından simgesel olarak bu üvey anne ölür, yani etkisiz hale gelir. Kız için çekirdek aile kesin biçimde değişmiştir” (Sezer, 2004, s. 12). 
olabildiği analizini yapabilmekteyiz (koşulsuz fiziksel güzellik, çekicilik).

Temel Kategori 2: Eve Bağımlı Kadın İmgesi:

Bu kategori altında çalışmamızda incelediğimiz iki masaldaki karakterlerin eve bağımlılığı ile ilişkileri analiz edilecektir: "Saat 12'de büyü bozulacak ve her şey eski haline dönüşecek...” (47:48) (hava kararınca evde olmak, vaktinde eve dönmek). Eğer Sindirella saat gece yarısı 12'den önce evde olmazsa baloya geldiği at arabası balkabağına, arabanın sürücüsü güvercine ve atları fareye dönüşmektedir. Bu sahnede kız çocuklarına vaktinde evinde olmayanların başlarına kötü bir iş gelebileceği ifade edilmektedir. Burada sadece gelecek neslin kadınlarına değil aynı zamanda gelecek neslin erkeklerine de sembolik bir anlatımla bir mesaj verilmektedir: Geceleri eşlerinizi, kız kardeşlerinizi ve kız çocuklarınızı yalnız bir şekilde dışarı çıkarmamaları gerektiğidir.

Resim 8. Pamuk Prenses Sarayda Temizlik Yaparken

Eve bağımlı kadın kategorisinde incelenen temalardan biri kadının ev işleriyle meşgul olmasıdır. Örneklemimizdeki karakterlerden Pamuk Prenses (Bkz. Resim 8) ve Külkedisi (Bkz. Resim 4) sarayda yaşayan prensesler olmalarına rağmen çok eski kıyafetleriyle sarayın temizliğini tek başına yapmanın yanında, üvey anneleri ve üvey kardeşlerine hizmet de etmektedirler. $\mathrm{Bu}$ masalların sarayda yaşayan

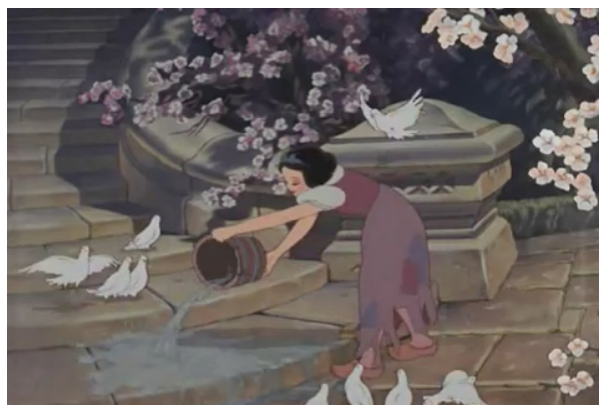
kişilere değil halka hitaben yazıldığından dolayı buradaki kadın figürünün ev işlerine yönlendirilmesi ve bu işlerin özendirilmesi ataerkil bir söylem için gerekli bir unsurdur. D1ş ses: “...Sindirella kendi evinde üvey annesi tarafindan hizmetçilik yapmaya zorlanmış ama yine de her şeye rağmen iyi kalpli nazik davranır her yeni günle tekrar umutlanıyormuş” (27:05) (Bkz. Resim 4).

Resim 9. Pamuk Prenses Cücelerin Evinde Temizlik Yaparken

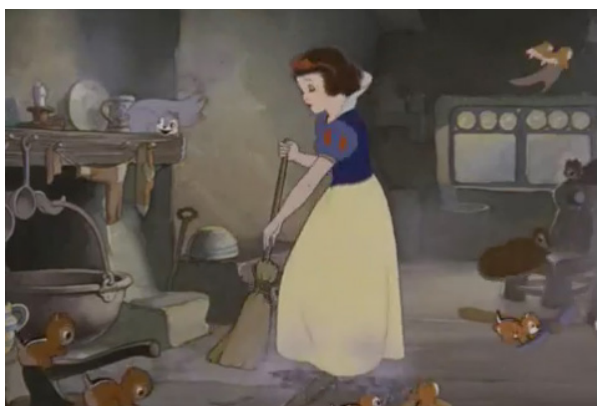

“... Üvey anne Pamuk Prenses’i paçavraların içinde hizmetçi olarak çalışmaya zorlamış" (01:42) (Bkz. Resim 8) (temizlik yapmak, hizmetçilik, ev işleriyle ilgilenmek, yemek yapmak), "Şikayet etmeden temizliğini yapar...” (03:42) (temizlik yapmak, hizmetçilik). Masal anlatıcısı bu ifadeleri kullanırken Sindirella ve Pamuk Prenses yaptığı işlerden memnun, mutlu bir yüz ifadesiyle temizliğine ve ev işlerine devam 
etmektedir (Bkz. Resim 4, 8 ve 9). Verilen görev temizlik yapmak gibi bir görev olmasina rağmen mutlak itaatle ve memnuniyetle vazifesini ifa etmektedir.

Pamuk Prenses yaşadığı sarayda temizlik yapmayı o kadar içselleştiriştir ki ormanda kaybolduğu esnada ilk kez gördüğü bir evin içerisine korkusuzca girmesinin ardından tanımadığı kişilerin yaşadığı evi hemen temizlemeye başlar, o da yetmez, yemek yapar (16:40) (Bkz. Resim 9) (temizlik yapmak, yemek yapmak, beceriklilik). Yapilan bu işler neticesinde masal anlatıcısı Pamuk Prenses'i “...becerikli Pamuk Prenses...” (21:38) sıfatı ile ödüllendirmekte, onun yaptığı işlerle yüceltmekte ve rol model olarak izleyicilere sunmaktadır. Cüceler eve geldiğinde yemeği ve temizliği çok beğenirler (37:21) ve Pamuk Prenses'in "Kalmama izin verirseniz ev işlerini ben yaparım, çamaşır, bulaşık yemek yeter ki kalmama izin verin." (38:10) (temizlik yapmak, yemek yapmak, hizmetçilik, ev işleriyle ilgilenmek) sözüyle cücelerin onayıyla birlikte cücelerin evinde kalmaya başlar.

"Süper kadın” metaforu, hayatın her alanında başarılı olması beklenilen fiziksel güzelliği ile bakımlı, ev işlerini ve yemekleri en güzel şekilde yapan, çocuklarının bakımında kusur göstermeyen ve aynı zamanda çalışan bir kadın olarak adlandırılmaktadır. Süper kadın imgesinin, incelenen masallarda birebir olarak karşılığı bulunmasa da Pamuk Prenses ve Sindirella'nın sarayın temizlik işlerini yapması, yemekleri yapması, çamaşırları yıkaması, hizmetçilik yapması, elbiselerin söküklerini dikmesi, evdeki hayvanların bakımını yapması, bahçenin bakımı ile ilgilenmesi gibi birçok faaliyeti bir arada yapması olarak karşımıza çıkmaktadır. Ancak prenseslerimiz bu durumdan en ufak bir şikâyet dahi etmemektedir. Topluma bu durumda nasıl davranılması gerektiğine dair bir rol model olmaktadırlar (!). Bu davranışlarıyla ancak çevrelerinden kabul gördüklerinden dolayı bu davranış kalıbını devam ettirmektedirler.

Resim 10. Prens Duvarın Üstünden Atlayıp Sarayın Bahçesine Girerken

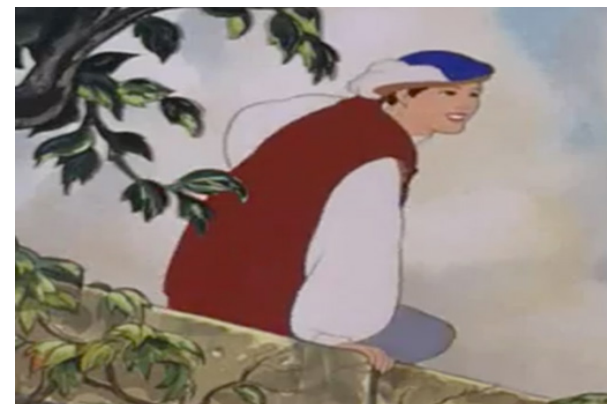

Pamuk Prenses masalındaki erkeklik imajı dışarıda özgürce dolaşarak tanıdığı tanımadığ ${ }_{1}$ herkesle konuşabilmektedir. Prens, Pamuk Prenses'in evine kimseden izin almaya ihtiyaç duymadan duvardan atlayarak girebilmektedir (05:23) (Bkz. Resim 10). Buna rağmen kadının geceleri dışarı çıkmaması, yalnız çıkmaması, vaktinde geri dönmesi, tanımadığı kişilerle konuşmaması ise defalarca tekrar edilmektedir. Bunun bir örneği Pamuk Prenses su kuyusundan su almaya gittiğinde prensi görünce hiç konuşmadan ve onu beğendiğini tavırları ile ona hissettirerek hemen evine kaçar, eve girdikten sonra da pencereden prense gülümser çünkü prensten hoşlanmıştır (05:26) ve artık evde olduğu için güvendedir (mekân olarak ev, yabancılarla konuşmamak). Buradaki verilen mesaj evde 
oturmamanın başına kötü işler açabileceği, bu kötü durumlara da özellikle erkekler tarafından maruz bırakılabileceği şeklinde olduğu değerlendirilmektedir.

Temel Kategori 3: İtaatkâr Kadın ve Erkeğin Sorgulanamaz Otoritesi

Kadınlar ataerkil kuralların işlediği toplumsal bir düzende yaşamakta zorlanıyor olsalar da bu toplumsal baskıya karşı çıkmak o kadar kolay olmamaktadır. Bu hegemonik sistemde kadın olmak erkeğin otoritesini kabul etmekle eşdeğer kabul edilmektedir. İncelenen bu masallarda Pamuk Prenses ve Külkedisi yaşadıkları kötü günler neticesinde her türlü acıya alışmış, kendisine yapılan fizikî ve psikolojik baskılara rağmen hiçbir zaman karşı gelmeyen ve otoriteye mutlak itaat eden bir karakterdedirler. $\mathrm{Bu}$ masallarda çektiği acılar yüzünden harap olmuş Pamuk Prenses ve Külkedisi yüceltilmekte onların üvey anneleri ve üvey kardeşleri ise eleştirilmektedir. Diğer taraftan yaşadığı acılardan dolayı evden ayrılan kadınlar ataerkil söylem tarafından kabul görmemektedir. Pamuk Prenses üvey annesinin talimatıyla avcı tarafından öldürülmek için götürülüp daha sonra avcının insafa gelmesi neticesinde kaçması için serbest b1rakılmıştır yani dolaylı olarak evden kovulmuştur (08:32) (otoriter erkek, itaatkâr kadın, eve bağlılık). Yaşadığı tüm olumsuzluklara rağmen evini terk etmeyen ve otoriteye karşı gelmeyen "itaatkâr kadınlar” ise mutlu sonla ödüllendirilmektedir. Sindirella saat gece yarısı 12'yi vurmadan önce balodan çıkar ve bu itaatinin karşılığını masalın sonunda mutlu sonla ödüllendirilerek almaktadır (55:03) (itaatkâr kadın, vaktinde eve dönmek, eve bağlılık).

İncelenen bu masallarda itaatkâr kadın imgesine karşılık bunun karşıt unsuru ve bu imgenin yeniden üretimini sağlayan otoriter erkek figürü vurgulanmıştır. Bu unsur masallarda kadın imgesindeki gibi doğrudan değil daha dolaylı bir anlatımla anlatılmaktadır.

\section{Resim 11. Baloda Prensin Kadınları Kabulü}

Sindirella masalında kralın evlenilecek yaşta kızları fermanla saraya toplaması, baloya gelen kızları prensin iki basamak yukarıda kabul etmesi, kızların önünde diz çökerek selamlamasını beklemesi (49:15) (Bkz. Resim 11), cücelerin hizmetçiliğini yapması karşısında cücelerin izin vermesi ile birlikte Pamuk Prenses'in onlarla yaşayabileceği (38:10), prensin Pamuk Prenses'i uyurken öpmesi (85:02)

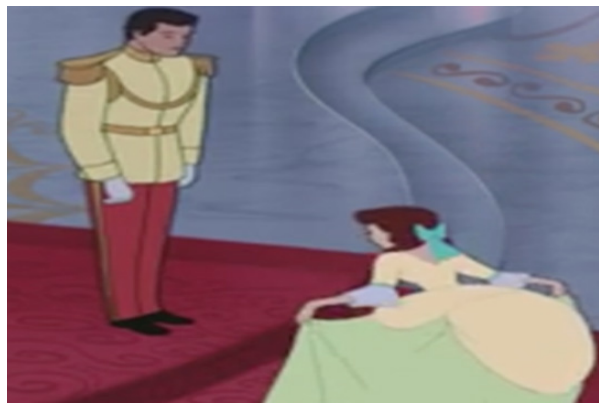
sahnelerinde kadının edilgen erkeğin ise etken rollerde olduğu açık bir şekilde ortaya konulmakta ve erkeğin otoritesi bu şekilde sembolize edilerek kadının iradesi elinden alınmaktadır. Aynı zamanda kadını erkek karşısında meta konumunda göstermektedir (otoriter erkek, itaatkâr kadın). 
Temel Kategori 4: Kadının Bağımsızlık Korkusu

Sindirella'nın baloda giyeceği kıyafetler evdeki sevimli hayvanlar tarafindan hazırlanmaktadır. Hazırlanan bu kıyafeti gören kardeşleri kıskançlıklarından kıyafeti parçalarlar. Bu kez de bir peri tarafından Sindirella’ya baloya gitmek için gerekli olan her şey verilmektedir. Aynı şekilde Pamuk Prenses ormanda kaybolduğunda hayatını idame ettirebilmek için hiç tanımadığı yedi bekâr adamın evinde hizmetçilik yapma pahasına kalmayı, onların koruması altına girmeyi istemektedir. Bu sahnelerden çıkarılan ise kadının tek başına yeterli olamayacağı, hayatının her safhasında birilerine muhtaç yaşamak zorunda olduğu algısını oluşturmaktır. Böylece kadınların erkeklere bağımlı olmadan yaşayabilmesinin mümkün olmayacağı algısı küçük izleyici kitlesi olan çocukların bilinçaltına işlenmektir.

Sindirella ve Pamuk Prenses, üvey anneleri ve üvey kardeşlerinden masalın farklı bölümlerinde eziyet, hakaret, duygusal şiddet görmelerine rağmen kendi bağımsızlıklarını gösterememektedir. Buna rağmen, bu şekilde baskılar altında olsalar da kendi evlerinde başkalarına bağımlı bir şekilde yaşamayı dışarıda bağımsız bir şekilde yaşamaya tercih etmektedirler.

Masalın sonunda Sindirella da Pamuk Prenses de henüz tanımadıkları prens ile evlenirler. Sindirella ve Pamuk Prenses annesinin yokluğu babasının ilgisizliği ile karşı karşıya kalan kızlar için prensin ilgisi sonsuz bir baş dönmesi yaratmıştır ve bu kavram "çocuklukta doyumsuz kalan sevgi ihtiyacı, kendini bir başkasına bırakmaya yönelik pasif, ama potansiyel açıdan yıkıcı bir arzuya yol açan bir durum" (Dowling, 1999, s. 82) şeklinde Sindirella kompleksi ${ }^{6}$ olarak literatürdeki yerini almıştır.

Temel Kategori 5: Kadına Atfedilen Duygusallık İmgesi

İncelenen masallarda bu kategori şu sahnelerle işlenmektedir: Sindirella sabah uyanır uyanmaz yine rüya gördügünü söyler, bunun üzerine dilek tutar ve şarkı söylemeye başlar (04:00) (pembe düş, rüya). Erkekler kral ve yönetici rollerinde görünmektedir. Kadınlar kraliçe de olsa prenses de olsa ev işleriyle ve çocuk bakmakla meşguldürler ve anaç rolleriyle ön plandadır. Yönetime herhangi bir müdahaleleri mümkün değildir. Pamuk Prenses masalında, kraliçe şatonun penceresinde nakış yaparken dışarıyı seyretmektedir ve aynı anda hayallere dalar (01:02). Pembe düşlere dalan kraliçe dikkatsizliği neticesinde aniden eline iğne batar ve yapmakta olduğu elindeki işlemeye kan bulaşır. Fakat eline iğne battığında kraliçenin canının yanmasına dair en ufak bir belirti göstermezken, elinden damlayan kana bakar ve iç çekerek "Ah keşke benim de böyle kan gibi kırmızı dudaklı, kar gibi beyaz tenli siyah saçlı bir kızım olsa..." şeklinde bir dilekte bulunur (anaç, duygusal). Burada, anne olmanın önemi vurgulanmaktadır. Anne olabilmek kadının kendi canından daha önemli olduğu sembolik bir anlatım dili ile sahnelenmektedir.

6 Ayrıntılı bilgi için bkz. Dowling, C. (1999). Sindirella Kompleksi: Çagdaş Kadında Bağımsızlık Korkusu. (Selçuk Budak Çev.). Ankara: Öteki Yayınları. 
Kadının duygusal, her an ağlayabilen, şefkatli, anaç ve sevecen özellikleri ön planda tutulmuştur. Kadına atfedilen bütün bu özellikler masalda ise yeniden üretilmektedir. Pamuk Prenses’in avcı tarafından ormana öldürülmek için götürülüp daha sonra dış sesin anlatımıyla “...masumluğuna, sevecenliğine dayanamaz ve Pamuk Prenses'e kıyamaz.” (08:34) ve öldürmekten vazgeçer burada masumluk, sevecenlik hayat kurtarıcı olacak kadar önemli bir özellik olarak vurgulanmaktadır.

Resim 12. Pamuk Prenses Ormanda Kaybolduğunda Ağlarken

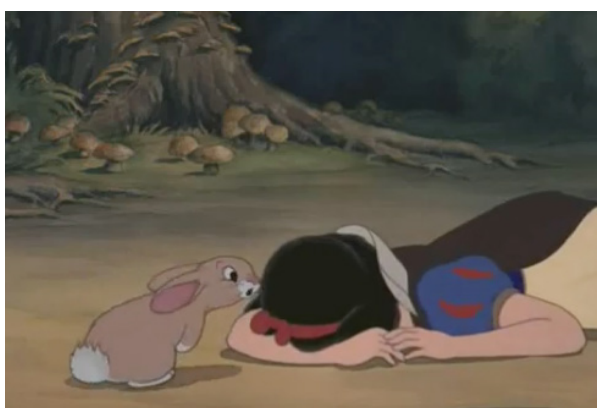

Pamuk Prenses ormanda kaybolduğunda; gündüz vakti ve ormanda kimse olmamasına rağmen ağaçlardan, kuşlardan, dallardan korkar, kendini bir köşeden bir köşeye savurur ve en sonunda dayanamaz, oturduğu yerde ağlayarak kalakalır (09:34) (Bkz. Resim 12). Cücelerin evine yerleşen ve akşamları onlara yemek hazırlayan $\mathrm{Pa}$ muk Prenses, cüceler ondan yaşça çok fazla büyük olmasina rağmen merhametle ve sevecenlikle onları "Çocuklar haydi yemeğe." diye çağırmaktadır. Onlardan büyükmüş gibi tavır ve davranışlar sergileyerek onlardan daha olgun bir profil çizmektedir (anaç, sevecen, merhametli, narin, ağlamak).

Resim 13. Sindirella Elbiseleri Yırtıldığı İçin Ağlarken

Sindirella baloya gideceği elbiseyi hazırlayıp üvey kardeşleri ile beraber çıkacakken üvey kardeşleri Sindirella’yı hırsızlıkla suçlamaktadır ve büyük emekle hazırlanan elbiseyi paramparça etmişlerdir (42:01). Onu hırsızlıkla suçlamalarına rağmen Sindirella'nın ağzından en ufak bir kötü söz çıkmamıştır. Bu duruma en büyük tepkisi tek başına bir köşeye çekilerek içten içe ağlamak olmuştur (Bkz. Re-

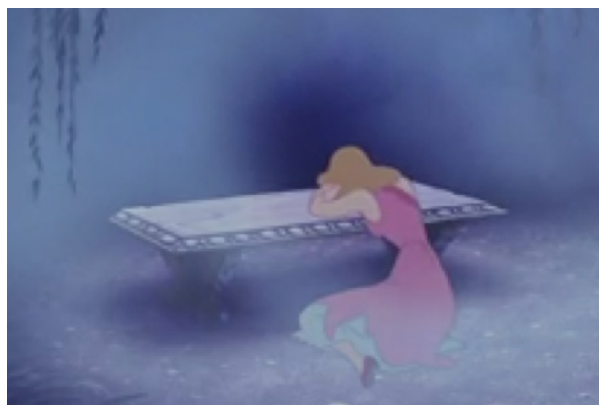
sim 13) (ağlamak, narin, duygusal, bağıml, itaatkâr). Bu sahnede masalın kadınlara dayattığı ideoloji şudur: "Sen sesini çıkarma, evini ve kalbini temiz tut. Biri kurtarır.” Bu anlayış ile kadın pasifize edilmekte, başına gelen kötü durumlardan kurtulması her zaman erkeğin onu kurtarması ile mümkün olacağı hususu vurgulanmaktadır. (Sezer, 2004, s. 54).

Temel Kategori 6: Kadın Korkusu

Masallardaki kötü kadın imajı yani “kötü kadını”, Pamuk Prenses ve Sindirella’nın 
üvey annesi rolünde görmekteyiz. Bu karakterlerde üvey anne ile öz anne arasında tam bir karşıtlık yaratılmaya çalışılmıştır. Üvey anne ne kadar olumsuz özelliklere sahipse öz anne bunun tam zıttı iyi özelliklere sahiptir. Bu özelliklerde gri alanlara yer bırakılmamıştır. Bu da izleyici kitlesinin iradesini hiçe saymak ve onlara seçim hakkı sunmamak anlamını taşımaktadır. Bu masallarda üvey anne her zaman kötülük tasarlayan, kıskanç, düzen bozucu, kurnaz olandır. Burada ikinci evliliğin tasvip edilmemesine yönelik bir gönderme de bulunmaktadır. Ataerkil söylemde üvey anne olan, ikinci evliliğini yapan kadın yadırganmaktadır. Kadın evliliğindeki tüm sıkıntılara katlanmalı ve asla evliliğini sonlandırmamalıdır. "Yuvayı dişi kuş yapar" söylemleriyle bu durum pekiştirilmekte bu sözün aksini düşündügümüzde boşanmış kadın yuvasını bir arada tutamamış kadın olarak etiketlenmektedir. Fakat erkekler için ikinci evlilik erkekler için dışlanmanın aksine desteklenmektedir. Pamuk Prenses ve Yedi Cüceler masalında krala halkın -ki halk burada toplumsal söylemi yansitmaktadırtelkinleri bu durumu onaylar niteliktedir: “...Sayın kralım, halkımıza yeni bir kraliçe, Pamuk Prenses'e de anne lazım.” (01:30). İkinci evliliğini yapan erkek her zaman iyi baba rolünde iken kadın için bu durum üvey anne ve kötü kadın rolü olmaktadır.

Üveylik ve özlük durumlarındaki karşıtlık yalnızca anne üzerinden değil çocuklar üzerinden de kurgulanmıştır. Sindirella masalındaki üvey anne öz kızlarına iyi davrandığı ölçüde üvey kızı olan Sindirella'ya kötü davranmaktadır. Sarayda oturmalarına rağmen Sindirella’yı hizmetçi olarak kullanmakta ve psikolojik şiddet uygulamaktadır. Herkesin davetli olduğu prensin balosuna üvey kızlarının hazırlanması için tüm çabasını harcayan üvey anne üvey kızının baloya gitmesine dahi izin vermemektedir. Pamuk Prenses masalında üvey anne kendisini kızı ile güzellik yarışına sokmaktadır ve onu kıskanmakta ve bu kıskançlı̆̆ının ulaştığı son nokta olarak onu öldürtmeyi tasarlamıştır. Masalda kraliçenin Pamuk Prenses'e olan kıskançlı̆̆1 şu şekilde ifade edilmiştir: “...Gün geçtikçe güzelleşen Pamuk Prenses kötü kalpli kraliçenin canını sıkmaya başlamış...” (06:24). Üvey annenin yaşadığı bu kıskançlık sonucu Pamuk Prenses’i avcının aracılığıyla öldürtmek için ormana yollamış (08:26) fakat bu durumda başarılı olmayınca Pamuk Prenses’in evden uzaklaşması kıskançlığını dindirmemiş ve onu kırmızı bir elmayla zehirlemeye çalışmıştır (kıskançlık, kadın nefreti, kadın düşmanlığı). Bu durum, kadınlar arası rekabetin birbirinden nefret edecek şekle dönüşebileceği ve öldürmeye kadar varabileceğinin göstergesidir. Her iki masalda üvey anneler üvey kızlarını sevmediği gibi üvey kızların da üvey annelerinden bir sevgi beklentileri yoktur. Yaşadıkları bu sevgisizliği kabullenmişlerdir. Bu durum bir meşrulaştırma olarak değerlendirilmekte, topluma üvey anneden bir sevgi beklenilmemesi, zaten üvey kızlarını sevmeyeceği mesajı verilmeye çalışıldığının göstergesidir.

Masalın farklı kısımlarında üvey anneye yönelik sürekli olarak negatif tanımlamalar devam etmektedir: Masal anlatıcısı dış ses “...Kibirli ve kötü kalpli üvey anne güzel Pamuk Prenses'in..." (01:42), Cüceler: "Kraliçe acımasızdır, cadıdır, kötüdür, bütün büyüleri bilir, kendini görünmez yapabilir...” (36:01), diş ses "Büyü yapan üvey anne çirkin kadına dönmek pahasına Pamuk Prenses'i öldürmeyi göze alıyordu” (47:38) (büyücü, cadı, kötü, kadın nefreti, üvey anne, ikinci evlilik). 
Masalın bir kısmında cücelerin arasındaki konuşmalarda Pamuk Prenses'in evde olmasıyla ilgili hoşnutsuzluğunu dile getirmek için kadınların tanımlanmasına ilişkin kullanılan söz şu şekildedir: "Sizi uyarıyorum kadınlara uyarsanız sizi çiğner geçerler." (41:46) (kadın nefreti, kötü, kadın düşmanlığı).

\section{Sonuç ve Tartışma}

Çocukların gelişim süreçlerinde çok önemli bir argüman olan masallar renkli ve fantastik bir eğitim unsuru olarak çocuklara yüzyıllardır sunularak kullanılagelmiştir. Ataerkil düzen masalların çocuklar üzerindeki etkisinin farkında olacak ki toplumsal cinsiyetin üretilmesinde ilk yapıtaşlarından olma özelliğine sahip masalların içine ideolojilerini yerleştirmiş ve toplumsal cinsiyetin yeniden üretilmesinde masalları kullanmıştır. Bu çalışmada Pamuk Prenses ve Yedi Cüceler ile Külkedisi: Sindirella masallarını konu alan çizgi filmlerin toplumsal cinsiyet algısı ve rollerinin ataerkil söylem içerisinde nasıl yeniden üretildiğini ortaya koymak maksadıyla incelenmiştir. Bu iki çizgi film de kadının güzel olması, kadın korkusu, itaatkâr kadın modeli ve kadının bağımsızlık korkusu stereotipleri ataerkil bir söylemle toplumun egemen dili üzerinden kurgulanarak sunulmuştur.

İncelenen bu çizgi filmler toplumsal bilincin yansıması olarak görülmektedir. Bunun yanı sıra masallar fantastik ve sevimli olarak oluşturulan karakterler sayesinde toplum tarafından masum olarak değerlendirilmektedir. Ebeveynler tarafından şartsız kabullerle çocukların zihinsel ve sosyal gelişimlerinde yardımcı olması açısından önemli bir argüman olarak kullanılmaktadır.

Bu türden çizgi filmlerde kurgulanmış toplumsal cinsiyet algısı çocuklar üzerinden dizayn edilmeye çalışılmaktadır. Ataerkil söylemlerle kadına ait özellikler yeniden belirlenmektedir. Kadınların belirlenen bu özelliklerin dışına çıkmasına izin verilmemekte ve kadınları toplumun kalıp yargılarına hapsetmektedir. Bu bağlamdan değerlendirildiğinde, Foucault'nun panaptikon benzetmesi toplum tarafından dayatılan gizli baskıyı simgelemektedir (Foucault, 2000, s. 2). Bu gizli baskı yalnızca sinırları belirlemekte kalmayıp, belirlenen özellikler ile, kadını biçimlendirip o kılıfa girmeye zorlamaktadır. Özgünlüğe ve farklılığa yer verilmeyen tek tipleştirme modeli ile de kadını ve dolaylı olarak toplumu dizayn etme çabası görülmektedir.

$\mathrm{Bu}$ çalışmada açıkça görüldüğü şekliyle ataerkil söylemlerin yerleştirmeye çalıştığ1 ideolojilerden bir tanesi kadının ev işleriyle meşgul olması gerektiği ve kadının mekânının ev olmasıdır. Bu söylemin altında yatan gizil gerçek ise kadının özgürleşmesine engel olmak ve kadını erkeğe bağımlı bir nesne konumunda tutmaktır.

Toplumsal cinsiyet algısının neden kadınlar üzerinden kurgulandığı ve erkeğin çıkarlarına hizmet ettiği konusuna açıklık getirmek için odaklanılacak unsurların başında 
tabakalaşma ve iktidar ilişkileri gelmektedir. Erkeğin dünyaya gelmeden almış olduğu toplumsal statü sayesinde güç ilişkileri açısından toplum tarafından daha önde konumlandırılmıştır. Bu verili meşru otorite sayesinde erkek, kadınlar üzerinden iktidar kurmakta ve aralarındaki eşitsizlik mesafesini bu şekilde daha da arttırmaktadır. Toplumun dayattığı baskıcı davranış modelleri arasında sıkışan kadın ise bu davranış kalıplarını içselleştirmekte ve kendini erkeğe bağımlı hissetmektedir. Çalışmamızda belirtildiği gibi kendisine dayatılan bu sınırların dışına çıkmak isteyen kadın tipi kötü kadın olarak nitelendirilmekte ve yaptığı bütün kötülükler cezasız kalmamaktadır. Sembolik olarak kadının özgür iradesini elinden almayı ve onu bağımlı hale getirmeyi amaçlayan ataerkil toplum, ortaya koyduğu bu karakterlerle çocukları belli davranış kalıbına sokarak gelecek nesilleri bu şekilde yetiştirmeyi amaçlamaktadır.

Sonuç olarak bu çalışmada yapılan analizlerden; masalların, sosyal öğrenmeye en açık grup olan çocuklar üzerinde toplumsal cinsiyetin yeniden üretilmesinde son derece etkili olduğu değerlendirilmektedir.

\section{Kaynakça}

Abisel, N. (1994). Nasıl Yaşıyor, Nasıl Düşlüyoruz? Yerli Filmlerin Kurmaca Dünyasında Demokrasi. O. Onaran, N. Abisel, ve L. Köker (Düzenleyen) içinde, Türk Sinemasında Demokrasi Kavramının Gelişmesi (s. 74-132). Ankara: T.C. Kültür Bakanlığı Yayınları.

Ahıska, M. (1999). Genç Olmayan Gençler Üzerine Bir Deneme. Defter Dergisi (37), 11-19.

Akın, A., ve DEMİREL, S. (2003). Toplumsal Cinsiyet Kavramı ve Sağllğa Etkisi (Concept of Gender and Its Effects on Healt). Cumhuriyet Üniversitesi Tip Fakültesi Dergisi Halk Sağlığı Özel Eki, 25 (4), 73-82.

Alkan, A. ve Çakır, S. (2012). Osmanlı İmparatorluğu’ndan Modern Türkiye’ye Cinsiyet Rejimi: Süreklilik ve Kırılmalar. F. Alpkaya, ve B. Duru (Düzenleyen) içinde, 1920'den Günümüze Türkiye'de Toplumsal Yapı ve Değişim (s. 197-239). Ankara: Phoenix Yayınları.

Beauvioir, S. (1997). Kadın İkinci Cins 1: Genç Kızlık Çağı (B. Onaran, Çeviren). İstanbul: Payel Yayınevi.

Bee, H., ve Boyd, D. (2009). Çocuk Gelişim Psikolojisi (O. Gündüz, Çeviren). İstanbul: Kaknüs Yayınları.

Bilican Gökkaya, V. (2015). Ahtapot Kadınlar: Aile Ve İş Yaşamı Kıskacındaki Kadınlar Ve Karşılaştıkları Sorunlar. Turkish Studies International Periodical for the Languages, Literature and History of Turkish or Turkic. 10 (10), 233-248.

Cesur, S. ve Paker, O. (2007). Televizyon ve Çocuk. Çocukların Tv Programlarına İlişskin Tercihleri. Elektronik Sosyal Bilimler Dergisi, 6 (19), 106-125.

Cihangir, S. ve Demir, Y. (2003). 3-6 Yaş Çocuklarının Anne-Babalarının Televizyon İzleme Özellikleri. İzmir, Kuşadası: OMEP Dünya Konsey Toplantısı.

Connel, R. W. (1998). Toplumsal Cinsiyet ve İktidar (C. Soydemir, Çeviren). İstanbul: Ayrınt1 Yayınları. 
Cressell, J. W. (2007). Qualitative Inquiry ve Research Desing. Thousand Oaks, CA: Sage.

Çalışır G. ve Okur Çakıcı F. (2015). Toplumsal Cinsiyet Bağlamında Sosyal Medyada Kurulan Benlik İnşasının Temsili. Turkish Studies International Periodical for the Languages, Literature and History of Turkish or Turkic Volume 10 (10), 267-290.

Deaux, K. (1987). Putting Gender Intı Context: An Interactive Model of Gender-Related Behavior. Psychological Review, 94 (3), 369-389.

Delphy, C. (1999). Baş Düşman Patriyarkının Ekonomi Politiği (H. Öz, ve L. Aykent, Çeviren). İstanbul: Saf Yayıncılık.

Dennison, B., Russo, T., Burdıck, P., ve Jenkıns, P. (2004). An Intervantion to Reduce Television Viewing by Preschool Children. Archives of Pediatrics and Adolescent Medicine, 158 (2), 170-178.

Dewey, J. (1996). The Collected Works of John Dewey: The Electronic Edition (A. Hickman, Düzenleyen). L.A.: Intelex Coprporation.

Dowling, C. (1999). Sindrella Kompleksi: Çağdaş Kadında Bağımsızlık Korkusu (S. Budak, Çeviren). Ankara: Öteki Yayınları.

Ekici, A. (2007). 1980-1990 Arası Türk Sinemasında Kentsel Ailede Kadının Konumu. Ankara: Ankara Üniversitesi Sosyal Bilimler Enstitüsü Yayımlanmamış Yüksek Lisans Tezi.

Foucault, M. (2007). Özne ve İktidar (O. Akınhay, ve I. Ergüden, Çeviren). İstanbul: Ayrıntı Yayınları.

Franzoi, L. (1996). Social Psychology. Dubuque: IA Brown ve Bencmark.

Göçgün, Ö. (2004). Türk Dünyası Edebiyat Tarihi 2. Cilt. Ankara: Atatürk Kültür Merkezi Başkanlığ1.

Güzel, B. (2015). Lysıstrata: Kadının Antik Yunan Toplumundaki Yeri. Turkish Studies-International Periodical for the Languages, Literature and History of Turkish or Turkic, 10 (10), 505-522.

Hall, S. (1998). Eski ve Yeni Kimlikler, Eski ve Yeni Etniklikler içinde, Kültür, Küreselleşme ve Dünya Sistemi (G. Seçkin, ve Ü. H. Yolsal, Çeviren). Ankara: Bilim ve Sanat Yayinları.

Hans, G. (2006). Kadın Psikolojisi (K. Şipal, Çeviren). İstanbul: Cem Yayınevi.

Illich, I. (1996). Gender (A. Fethi, Çeviren). Ankara: Ayraç Yayınları.

Junk, K. G. (1996). Analitik Psikolojinin Temel İlkeleri/Konferanslar (K. Şipal, Çeviren). İstanbul: Cem Yayınevi.

Lips, H. M. (2001). Sex and Gender: An Introduction. California: Mayfield Publishing Company.

Lorber, J. (1994). The Construction of Gender, In Reconstructing Gender: A Multicultural Antology. New York: Sage.

Merriam, H. (2013). Nitel Araştırma: Desen ve Uygulama İçin Bir Rehber (S. Turan, Çeviren). Ankara: Nobel Yayıncilık.

Neuman, W. L. (2011). Toplumsal Araştırma Yöntemleri 1-2 (S. Özge, Çeviren). İstanbul: Yayın Odası Yayınları.

Propp, V. (2001). Masalın Biçimbilimi (M. Rifat, ve S. Rifat, Çeviren). İstanbul: Om Yayınlar1.

Saydam, M. B. (1997). Deli Dumrul'un Bilinci. İstanbul: Metis Yayınları.

Scott, W. J. (2007). Toplumsal Cinsiyet: Faydah Bir Tarihsel Analiz (A. T. Kılıç, Çeviren). İs- 
tanbul: Agora Yayınları.

Sezer, M. Ö. (2004). Masallarda Toplumsal Cinsiyetin İşlenişi. Doktora Tezi, Ankara Üniversitesi, Sosyal Bilimler Enstitüsü Kadın Çalışmaları Anabilim Dalı, Ankara.

Şirin, M.R. (2006). Televizyon Çocuk ve Aile: Yeni Çocukluğun Televizyon Sarmalı. İstanbul: İz Yayıncilık.

Türmen, T. (2003). Toplumsal Cinsiyet ve Kadın Sağlığı. Toplumsal Cinsiyet, Sağlık ve Kadın (s. 3-17) içinde, Ankara: HÜKSAM Yayınları.

Wharton, A. S. (2009). The Sociology of Gender: An Introduction to Theory and Research. Chichester: Blacwell Publishing.

Yağan Güder, S. (2014). Okul Öncesi Dönemdeki Çocukların Toplumsal Cinsiyet Algılarının İncelenmesi. Yüksek Lisans Tezi, Hacettepe Üniversitesi, Eğitim Bilimleri Enstitüsü Müdürlüğü İlköğretim Anabilim Dalı Okul Öncesi Eğitimi Bilim Dalı, Ankara.

Yıldırım, E. (2008). Çocuk ve Televizyonda Şiddet: 5 Yaşındaki Çocukların Anne-Babalarının Televizyondaki Şiddetin Saldırgan Davranışlar Üzerindeki Etkilerine İlişkin Görüşleri. Yayımlanmamış Yüksek Lisans Tezi. Ankara: Gazi Üniversitesi, Eğitim Bilimleri Enstitüsü, Çocuk Gelişimi ve Eğitimi Anabilim Dalı, Ankara.

Zoonen, L. (1997). Feminist Media Perspectives. University Of Wasl. 